\title{
Growth and grazing responses of the mixotrophic dinoflagellate Dinophysis acuminata as functions of light intensity and prey concentration
}

\author{
Sunju Kim ${ }^{1,5}$, Yi Gu Kang ${ }^{1}$, Hyung Seop Kim², Wonho Yih ${ }^{1}$, D. Wayne Coats ${ }^{3}$, \\ Myung Gil Park ${ }^{4, *}$ \\ ${ }^{1}$ Department of Oceanography, Kunsan National University, Gunsan, 573-701, Republic of Korea \\ ${ }^{2}$ Gunsan Fisheries Office, NFRDI, Gunsan 573-882, Republic of Korea \\ ${ }^{3}$ Smithsonian Environmental Research Center, PO Box 28, Edgewater, Maryland 21037, USA \\ ${ }^{4}$ Laboratory of HAB Ecophysiology (LOHABE), Department of Oceanography, Chonnam National University, Gwangju, \\ 500-757, Republic of Korea \\ ${ }^{5}$ Present address: Smithsonian Environmental Research Center, PO Box 28, Edgewater, Maryland 21037, USA
}

\begin{abstract}
Dinophysis acuminata, a photosynthetic marine dinoflagellate, possesses plastids of cryptophyte origin and causes diarrhetic shellfish poisoning (DSP). Recent work has shown D. acuminata to be a mixotroph that grows well when feeding on the photosynthetic ciliate Myrionecta rubra. Using established cultures, we examined the effects of light intensity and prey ( $M$. rubra) concentration on growth and ingestion rates of D. acuminata. Growth rates increased with increasing prey concentration under continuous illumination of $60 \mu \mathrm{E} \mathrm{m}^{-2} \mathrm{~s}^{-1}$, with maximum mixotrophic growth $\left(0.91 \mathrm{~d}^{-1}\right)$ almost 5 times higher than growth in the absence of prey $\left(0.19 \mathrm{~d}^{-1}\right)$. The maximum ingestion rate of $D$. acuminata was $1296 \mathrm{pg}$ C Dinophysis ${ }^{-1} \mathrm{~d}^{-1}\left(3.2\right.$ M. rubra cells Dinophysis $\left.{ }^{-1} \mathrm{~d}^{-1}\right)$ for data fitted to a Michaelis-Menten equation. Growth rate also increased with increasing light intensity, an effect even stronger when prey was supplied. Increased growth with increasing irradiance was accompanied by a corresponding increase in ingestion. While $D$. acuminata continued to grow in semi-continuous food-replete cultures at high $\left(200 \mu \mathrm{E} \mathrm{m}^{-2} \mathrm{~s}^{-1}\right)$ and low $\left(10 \mu \mathrm{E} \mathrm{m} \mathrm{m}^{-2} \mathrm{~s}^{-1}\right)$ light intensity, it failed to grow in darkness, despite the presence of prey. Our results suggest that $D$. acuminata is an obligate mixotroph that requires both light and prey for long-term survival. Results indicate that Dinophysis species are typically prey-limited in the field.
\end{abstract}

KEY WORDS: Dinophysis acuminata $\cdot$ Myrionecta rubra $\cdot$ Growth $\cdot$ Grazing $\cdot$ Light $\cdot$ Mixotrophy · Phagotrophy Resale or republication not permitted without written consent of the publisher

\section{INTRODUCTION}

The marine dinoflagellate genus Dinophysis Ehrenberg includes both photosynthetic and non-photosynthetic species. Dinophysis species are globally distributed in tropical and temperate marine environments over a broad range of salinities, although usually found in low abundances (mostly $<100$ cells $\mathrm{l}^{-1}$; Nishitani et al. 2002, 2005). Photosynthetic species in this genus, however, have been reported to cause dense blooms (up to $10^{7}$ cells $\mathrm{l}^{-1}$ ) responsible for diarrhetic shellfish poisoning (DSP) in many parts of the world (Yasumoto et al. 1980, Hallegraeff \& Lucas 1988, Lee et al. 1989). Due to the impact of DSP on aquaculture and human health, photosynthetic Dinophysis are recognized as a harmful algal bloom (HAB) species of socioeconomic importance. Nonetheless, the biology, ecophysiology, and toxicology of these species are not 
well understood, as photosynthetic Dinophysis have only recently been cultured and maintained in the laboratory (Park et al. 2006).

Dinophysis acuminata Claparède et Lachmann is a photosynthetic species that contains cryptophyte-like plastids (Schnepf \& Elbrächter 1988). Despite the presence of plastids, long-term growth has never been sustained in any culture medium (e.g. f/2 medium) known to support growth of other phytoplankton species (e.g. Sampayo 1993, Granéli et al. 1997). Setälä et al. (2005) noted that plastids of $D$. acuminata incubated in the laboratory showed reduced yellow-orange fluorescence, became smaller, and gradually aggregated into 1 or 2 'packages' over time. Light and electron microscopic observations on $D$. acuminata have revealed the presence of feeding structures, including food vacuoles and a peduncle-like arrangement of microtubular ribbons (Lucas \& Vesk 1990, Jacobsen \& Anderson 1994, Koike et al. 2005). In addition, recent molecular reports have proven that the plastid 16S rRNA and $p s b A$ genes of $D$. acuminata are identical to those of the cryptophyte Teleaulax amphioxeia (Takishita et al. 2002, Janson \& Graneli 2003, Janson 2004, Minnhagen \& Janson 2006). These studies support the notion that plastids in D. acuminata are kleptoplastids derived from prey containing a plastid of cryptophyte origin. If true, then $D$. acuminata is likely mixotrophic, capable of utilizing phagotrophic and photosynthetic nutritional strategies.

Although a number of heterotrophic dinoflagellates are known to retain prey plastids (e.g. Larsen 1988, Fields \& Rhodes 1991, Skovgaard 1998, Lewitus et al. 1999a, Jakobsen et al. 2000, Eriksen et al. 2002), the relative importance of phagotrophy and photosynthesis for growth and survival of kleptoplastidic dinoflagellates is not well understood. The few studies that have addressed this issue (e.g. Skovgaard 1998, Jakobsen et al. 2000) indicate that kleptoplastids enhance growth and survival by providing an alternative carbon source when food is limited.

Recently, Park et al. (2006) successfully established Dinophysis acuminata in laboratory culture and reported that it uses a peduncle to extract and ingest cell contents of its prey organism, a plastidic ciliate Myrionecta rubra (= Mesodinium rubrum), itself a consumer of cryptophytes. Using cultures of D. acuminata, we explored (1) the effects of prey ( $M$. rubra) concentration on $D$. acuminata growth and ingestion, and (2) the effects of irradiance on the phototrophic growth, feeding, and mixotrophic growth of D. acuminata. Ecophysiological responses of this species, including species-specific feeding and growth characteristics, provide new insights into Dinophysis autecology, vertical distribution patterns, and environmental conditions that underline bloom dynamics.
Expanding knowledge about the autecology of Dinophysis species may improve predictive capabilities necessary for optimal management of shellfish industries affected by DSP.

\section{MATERIALS AND METHODS}

Cultures. Dinophysis acuminata (strain DA-MAL01) was isolated from Masan Bay, Korea, in December 2005 and grown in $30 \mathrm{psu} \mathrm{f} / 2$-Si medium at $20^{\circ} \mathrm{C}$ under continuous illumination of $60 \mu \mathrm{E} \mathrm{m} \mathrm{m}^{-2} \mathrm{~s}^{-1}$ (Park et al. 2006). Stock cultures were maintained as $\sim 200 \mathrm{ml}$ volumes in $250 \mathrm{ml}$ polycarbonate bottles and fed by adding 5 to $10 \mathrm{ml}$ of the ciliate Myrionecta rubra (strain MR-MAL01) as prey every 2 to $3 \mathrm{~d}$. Immediately after adding prey, densities of $D$. acuminata and $M$. rubra were approximately equal. Stock cultures were diluted 1:9 with fresh medium and transferred to clean polycarbonate bottles at weekly intervals. The ciliate prey were maintained under the above conditions and fed the cryptophyte Teleaulax sp. at approximately $5 \mathrm{~d}$ intervals as described by Yih et al. (2004).

Growth and grazing responses as functions of prey concentration. Growth and grazing responses of Dinophysis acuminata were determined over Myrionecta rubra densities ranging from 0 to 10000 cells ml ${ }^{-1}$. Stock cultures of $D$. acuminata and $M$. rubra were diluted using fresh f/2-Si medium and distributed to $500 \mathrm{ml}$ polycarbonate bottles to achieve triplicate treatments with target predator/prey concentrations (cells ml $\mathrm{m}^{-1}$ ) of 5/10, 10/50, 20/100, 50/500, 100/1000, 300/3000, 500/5000, and 1000/10000. In addition, triplicate control bottles were established for prey only at densities as above and for predator only at 100 cells $\mathrm{ml}^{-1}$.

Aliquots $(5 \mathrm{ml})$ withdrawn from the bottles at the start of the experiment (Day 0) and at $24 \mathrm{~h}$ intervals over $7 \mathrm{~d}$ were fixed with acid Lugol's solution (final concentration of $2 \%$ ). Abundances of Dinophysis acuminata and/or Myrionecta rubra were estimated for each Lugol's-fixed sample by scanning triplicate Sedgwick-Rafter chambers at $100 \times$ magnification (Olympus BX 50). Cells present in optical transects of each chamber were summed until the entire chamber was examined, or until $>200$ cells were counted. Growth rates $(\mu$, $\mathrm{d}^{-1}$ ) for D. acuminata and $M$. rubra were calculated for each sampling interval using the following exponential growth equation:

$$
\mu=\frac{\ln N_{1}-\ln N_{0}}{t_{1}-t_{0}}
$$

where $N_{1}$ and $N_{0}$ are cell concentrations at time $t$ and time 0 , respectively, and $t_{1}-t_{0}$ is the time interval between samplings. From these data, 0 to $48 \mathrm{~h}$ was 
selected as the optimal interval for calculating predator growth, as D. acuminata abundance increased steadily and prey density was reduced by less than $50 \%$. Data for growth rates during the optimal interval were fitted to a modified Michaelis-Menten model that included a positive $y$-axis intercept, as D. acuminata is photosynthetic and continues to grow for several days in the absence of prey. Parameters for the modified Michaelis-Menten model were estimated using SigmaPlot software (Version 9.01, MMIV Systat Software) and the equation:

$$
\mu=\frac{\mu_{\max }\left(x-x^{\prime}\right)}{K_{\mathrm{m}}+\left(x-x^{\prime}\right)}
$$

where $\mu$ is growth rate of $D$. acuminata, $\mu_{\max }$ is maximum growth rate, $x$ is prey ( $M$. rubra) concentration (cells $\left.\mathrm{ml}^{-1}\right), x^{\prime}$ is compensation point of prey concentration where growth is $0(\mu=0)$, and $K_{\mathrm{m}}$ is prey concentration sustaining $1 / 2 \mu_{\max }$.

Ingestion rate $\left(I\right.$, as prey predator ${ }^{-1} \mathrm{~h}^{-1}$ ) for Dinophysis acuminata was calculated according to Frost (1972), with adjustment for predator growth following Heinbokel (1978) and refined by Jeong \& Latz (1994). Specifically, ingestion rates were calculated as:

$$
I=[C] F \times 24
$$

where $[C]$ is mean prey (Myrionecta rubra) concentration (cells ml-1) averaged for incubation time for treatment bottles, and $F$ is the clearance rate (volume predator $^{-1} \mathrm{~h}^{-1}$ ):

$$
F=V g[P]^{-1}
$$

where $V$ is the volume $(\mathrm{ml})$ of cultures in experimental bottles, $g$ is the grazing constant $\left(\mathrm{h}^{-1}\right)$, and $[P]$ is mean number of predators in treatment bottles averaged for incubation time:

$$
[P]=\frac{P_{0}\left(\mathrm{e}^{\mu t}-1\right)}{\mu t}
$$

where $P_{0}$ is initial concentration of $D$. acuminata.

Growth and ingestion rates were plotted against mean prey concentration calculated as:

$$
[C]=\frac{C_{0}\left(\mathrm{e}^{t(\mathrm{k}-\mathrm{g})}-1\right)}{t(\mathrm{k}-\mathrm{g})}
$$

where $C_{0}$ is initial prey concentration in the treatments, and $\mathrm{k}$ is the prey growth constant, calculated as $\mathrm{k}=\ln \left(C_{t} / C_{0}\right) / t$, where $C_{t}$ is final prey concentration in control bottles after incubation for time $t(\mathrm{~h})$. The grazing constant (g) was calculated as:

$$
\mathrm{g}=\mathrm{k}-\frac{\ln \left(\left[C_{t}\right] /\left[C_{0}\right]\right)}{t}
$$

where the final prey concentration $\left[C_{t}\right]$ in treatments reflects the effects of grazing and growth; $\left[C_{t}\right]=\left[C_{0}\right] \mathrm{e}^{t(\mathrm{k}-\mathrm{g})}$.
Short-term responses of growth and grazing as a function of light intensity. A 1 wk old stock culture of Dinophysis acuminata was acclimated at each of 3 different light intensities $\left(10,60,120 \mu \mathrm{E} \mathrm{m} \mathrm{m}^{-2} \mathrm{~s}^{-1}\right)$ for 3 to $4 \mathrm{~d}$. Each acclimated culture was diluted to $100 \mathrm{D}$. acuminata $\mathrm{ml}^{-1}$ using fresh medium and distributed to each of twelve $50 \mathrm{ml}$ tissue culture flasks as $50 \mathrm{ml}$ culture volumes. For each set of 12 flasks, 6 received Myrionecta rubra at saturating prey concentration $\left(1000 \mathrm{ml}^{-1}\right)$ and 6 received no prey, with 3 prey-replete and 3 prey-free treatments incubated at each of 2 light levels. Light levels used for incubation were 0 and $10 \mu \mathrm{E} \mathrm{m} \mathrm{m}^{-2} \mathrm{~s}^{-1}$ for the $10 \mu \mathrm{E} \mathrm{m}^{-2} \mathrm{~s}^{-1}$ acclimated culture, 30 and $60 \mu \mathrm{E} \mathrm{m} \mathrm{m}^{-2} \mathrm{~s}^{-1}$ for the $60 \mu \mathrm{E} \mathrm{m} \mathrm{m}^{-2} \mathrm{~s}^{-1}$ acclimated culture, and 120 and $200 \mu \mathrm{E} \mathrm{m}^{-2} \mathrm{~s}^{-1}$ for the $120 \mu \mathrm{E} \mathrm{m} \mathrm{m}^{-2}$ $\mathrm{s}^{-1}$ acclimated culture. Triplicate prey-only controls (1000 M. rubra $\mathrm{ml}^{-1}$ ) were incubated at each light level. Light intensities were measured with a radiometer (Model QSL-2101, Biospherical Instruments) placed near the center of $50 \mathrm{ml}$ tissue culture flasks filled with f/2-Si medium. Subsamples were taken every $24 \mathrm{~h}$ from each flask to estimate abundance of predator and prey. An optimal incubation time of $72 \mathrm{~h}$ was chosen for calculating growth and ingestion rates, as that interval gave the highest growth rate and showed no depletion of prey (i.e. less than $50 \%$ reduction in prey density). Growth and ingestion rates were calculated as explained above, with growth in the presence and absence of prey representing mixotrophic and phototrophic growth, respectively.

Growth efficiency (GE, \%) was defined as predator carbon produced per prey carbon ingested. GE of Dinophysis acuminata at each light treatment was calculated according to:

$$
\mathrm{GE}=\frac{\left(\mu_{\mathrm{mix}} \times C_{D-\operatorname{mix}}\right)-\left(\mu_{\mathrm{ph}} \times C_{D-\mathrm{ph}}\right)}{I \times C_{M}} \times 100
$$

where $\mu_{\text {mix }}$ and $\mu_{\mathrm{ph}}$ represent mixotrophic and phototrophic growth rates of $D$. acuminata in food-replete and prey-free culture, respectively, $I$ is ingestion rate (prey cells Dinophysis ${ }^{-1} \mathrm{~h}^{-1}$ ), and $C_{D \text {-mix }}, C_{D \text {-ph, }}$ and $C_{M}$ indicate cell carbon content in mixotrophic $D$. acuminata, phototrophic D. acuminata, and Myrionecta rubra, respectively. Cell carbon content was estimated from cell volume determined by measuring cell length and width using an ocular micrometer on an Olympus microscope at $200 \times$ magnification, with at least 30 cells measured per replicate for each light intensity. Cell volumes of $M$. rubra and $D$. acuminata were calculated using $V\left(\mu^{3}\right)=(\pi / 6) w^{2} \times 1$ (Johnson \& Stoecker 2005) and $(\pi / 6) w \times d \times 1$ (Vadrucci et al. 2007), respectively, where $w, d$, and $l$ are cell width, depth, and length, respectively. Carbon content was calculated from cell

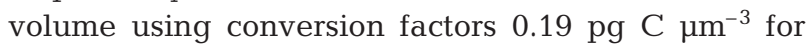
oligotrich ciliates (Putt \& Stoecker 1989) and carbon 
Table 1. Dinophysis acuminata feeding on Myrionecta rubra. Predator and prey concentrations, ratios, and growth rates for treatments assessing functional response. Initial concentration of prey $\left[C_{0}\right]$ and predator $\left[P_{0}\right]$; ratio of $\left[C_{0}\right]:\left[P_{0}\right]$, growth rate $(\mu)$ of predator, prey growth constant $(\mathrm{k})$, grazing constant $(\mathrm{g})$, mean concentrations of prey $([C])$ and predator $([P])$ averaged for $48 \mathrm{~h}$ incubations, and ratio of $[C]:[P]$. Data are shown as mean (SE in parentheses)

\begin{tabular}{|c|c|c|c|c|c|c|c|c|}
\hline $\begin{array}{l}{\left[C_{0}\right]} \\
(\text { cells ml } \\
-1\end{array}$ & $\begin{array}{c}{\left[P_{0}\right]} \\
\left(\text { cells ml }{ }^{-1} \text { ) }\right.\end{array}$ & {$\left[C_{0}\right]:\left[P_{0}\right]$} & $\underset{\left(h^{-1}\right)}{\mu}$ & $\begin{array}{c}\mathrm{k} \\
\left(\mathrm{h}^{-1}\right)\end{array}$ & $\underset{\left(h^{-1}\right)}{g}$ & $\begin{array}{c}{[C]} \\
\left(\text { cells } \mathrm{ml}^{-1}\right)\end{array}$ & $\begin{array}{c}{[P]} \\
(\text { cells ml } \\
\left.l^{-1}\right)\end{array}$ & {$[C]:[P]$} \\
\hline $6(1)$ & $5(1)$ & $1.2(0.3)$ & $0.014(0.001)$ & $0.044(0.003)$ & $0.006(0.004)$ & $16(1)$ & $7(2)$ & $2.4(0.5)$ \\
\hline $44(2)$ & $8(1)$ & $5.8(0.3)$ & $0.020(0.001)$ & $0.032(0.000)$ & $0.001(0.001)$ & $103(6)$ & $13(1)$ & $8.0(0.3)$ \\
\hline $80(2)$ & $17(3)$ & $5.1(1.2)$ & $0.017(0.000)$ & $0.037(0.002)$ & $0.010(0.004)$ & 163 (16) & $26(5)$ & $6.7(1.5)$ \\
\hline $461(22)$ & $41(6)$ & $11.6(1.7)$ & $0.031(0.001)$ & $0.032(0.002)$ & $0.008(0.001)$ & $883(77)$ & $94(12)$ & $9.6(1.3)$ \\
\hline 1005 (64) & $89(6)$ & $11.4(1.4)$ & $0.035(0.003)$ & $0.032(0.002)$ & $0.013(0.002)$ & $1659(50)$ & $196(28)$ & $9.0(1.8)$ \\
\hline 3265 (314) & $290(8)$ & $11.4(1.5)$ & $0.035(0.000)$ & $0.026(0.000)$ & $0.027(0.001)$ & 3236 (337) & $753(30)$ & $4.3(0.6)$ \\
\hline 5937 (168) & 588 (37) & $10.1(0.4)$ & $0.030(0.001)$ & $0.020(0.003)$ & $0.030(0.001)$ & 4749 (79) & $1302(86)$ & $3.7(0.2)$ \\
\hline $11118(200)$ & $1020(64)$ & $11.0(0.6)$ & $0.021(0.002)$ & $0.018(0.000)$ & $0.025(0.003)$ & 9448 (610) & $1776(42)$ & $5.3(0.2)$ \\
\hline
\end{tabular}
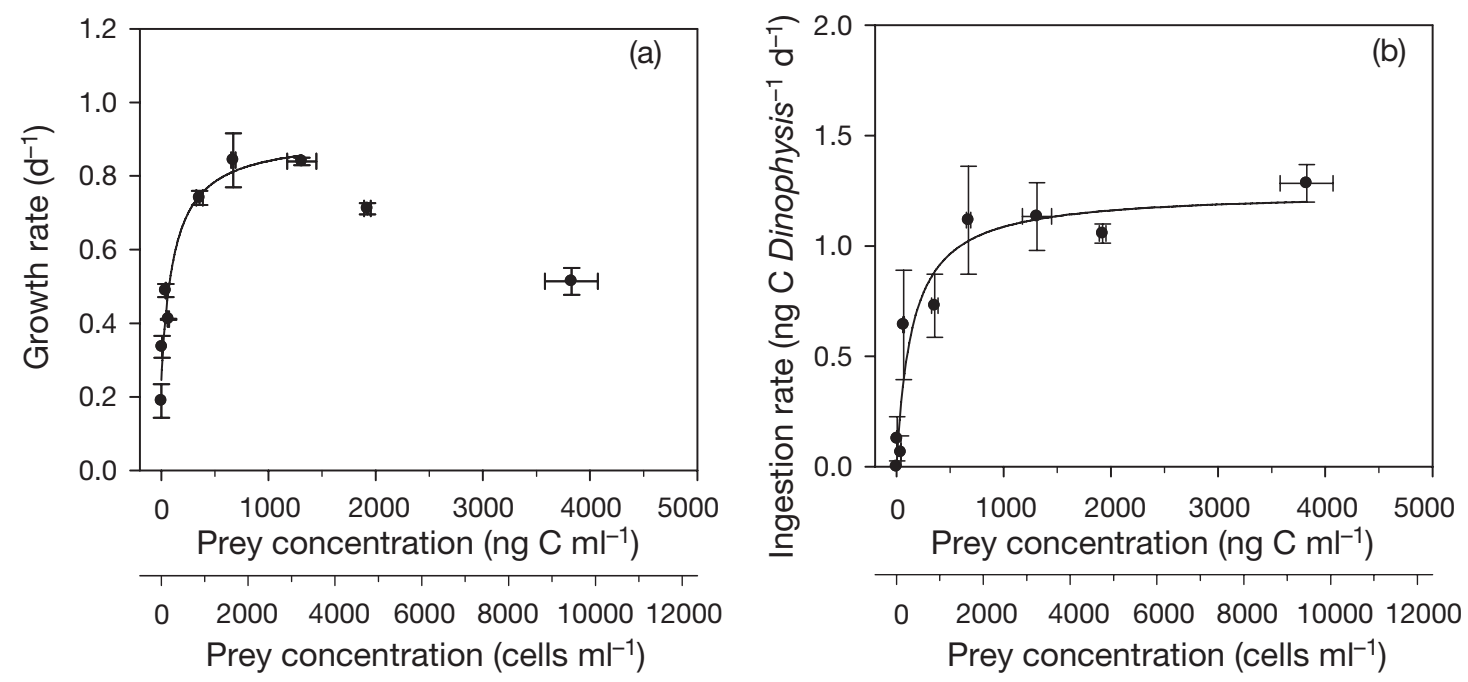

Fig. 1. Dinophysis acuminata. (a) Growth and (b) ingestion rates for the dinoflagellate as a function of mean prey density during $48 \mathrm{~h}$ incubations. Data points are shown as mean \pm SE for 3 replicates. Data were fitted to a modified Michaelis-Menten equation (Eq. 2) for growth and a Michaelis-Menten equation for ingestion. Growth rate $\left(\mathrm{d}^{-1}\right)=0.91(x+77.4) /[210.3+(x+77.4)], \mathrm{r}^{2}=0.96$; ingestion rate $\left(\mathrm{ng} \mathrm{C}\right.$ Dinophysis $\left.{ }^{-1} \mathrm{~d}^{-1}\right)=1.2 \mathrm{x} /(361.6+\mathrm{x}), \mathrm{r}^{2}=0.97$

$(\mathrm{pg})=0.216 \times\left(\text { volume }, \mu \mathrm{m}^{3}\right)^{0.939}$ for dinoflagellates (Menden-Deuer \& Lessard 2000).

Long-term effects of light intensity on growth kinetics. Growth kinetics of semi-continuous, foodreplete Dinophysis acuminata cultures were determined under 3 different light regimens: continuous high light $\left(200 \mu \mathrm{E} \mathrm{m}^{-2} \mathrm{~s}^{-1}\right)$, continuous low light $(10 \mu \mathrm{E}$

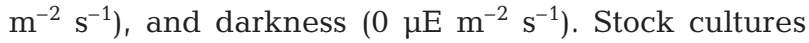
(1 wk old) of D. acuminata and Myrionecta rubra were acclimated for 2 to $3 \mathrm{~d}$ at 2 different light levels:

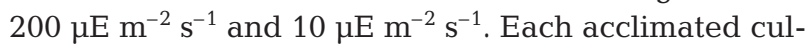
ture was diluted with fresh medium and distributed to eighteen $500 \mathrm{ml}$ polycarbonate bottles to establish 9 prey only controls with $2000 \mathrm{M}$. rubra $\mathrm{ml}^{-1}$ and 9 predator-prey treatments with 200 D. acuminata $\mathrm{ml}^{-1}$ and $2000 \mathrm{M}$. rubra $\mathrm{ml}^{-1}$. Bottles derived from the acclimated cultures were incubated in parallel with triplicate controls and triplicate treatments held at each of the 3 experimental light conditions. Samples taken from each bottle at the beginning of the experiment and at $24 \mathrm{~h}$ intervals over the following $21 \mathrm{~d}$ were fixed with acid Lugol's solution for determination of cell abundance as described above. At 4 to $5 \mathrm{~d}$ intervals, densities of $D$. acuminata and $M$. rubra were adjusted to initial predator and prey concentrations by addition of fresh medium and M. rubra. For the dark treatments, $D$. acuminata cultures were first concentrated by reverse filtration using $20 \mu \mathrm{m}$ screening and then returned to densities existing prior to screening by addition of fresh medium and prey. 


\section{RESULTS}

\section{Effects of prey concentration on growth and grazing of Dinophysis acuminata}

Mean abundances for Myrionecta rubra and Dinophysis acuminata at the start of incubations were very close to target densities and exhibited expected prey: predator ratios (Table 1). Growth and grazing rates for prey and predator resulted in changing densities and ratios over the following $48 \mathrm{~h}$. M. rubra showed positive net growth in treatments with the 5 lower initial prey densities, while net growth in treatments with the higher initial prey densities was non-positive. In contrast, growth of $D$. acuminata was positive in all treatments. Prey:predator ratios calculated from mean abundances during $48 \mathrm{~h}$ incubation were similar (6.7 to 9.0) for treatments with intermediate prey densities (Table 1). Values at saturating prey densities (i.e. above $\sim 2000 \mathrm{M}$. rubra $\mathrm{ml}^{-1}$ for growth and ingestion, see Fig. 1) were reduced by about half (3.7 to 5.3), while the mean prey:predator ratio for the lowest initial prey density was 2.4 .

Mixotrophic growth rates of Dinophysis acuminata increased sharply with mean prey concentrations up to $\sim 2000$ cells ml $^{-1}$, remained constant between 2000 and $\sim 3000$ cells $\mathrm{ml}^{-1}$, and decreased at prey densities above 3000 cells $\mathrm{ml}^{-1}$ (Fig. 1a). Maximum growth rate $\left(\mu_{\max }\right)$ was $0.91 \mathrm{~d}^{-1}$ when data were fitted to a modified Michaelis-Menten equation, with prey concentration sustaining $1 / 2 \mu_{\max }$ being 210 cells $\mathrm{ml}^{-1}$. By comparison, phototrophic growth rate of $D$. acuminata (i.e. growth in the absence of prey) was $0.19 \mathrm{~d}^{-1}$.

Ingestion rates of Dinphysis acuminata feeding on Myrionecta rubra increased with increasing prey concentration, with saturation occurring above $\sim 2000$ cells $\mathrm{ml}^{-1}$ (Fig. 1b). Maximum ingestion rate $\left(I_{\max }\right)$ was $1296 \mathrm{pg}$ C Dinophysis ${ }^{-1} \mathrm{~d}^{-1}$ (3.2 cells Dinoph$y_{\text {sis }}{ }^{-1} \mathrm{~d}^{-1}$ ) when fitted to a Michaelis-Menten equation, while prey concentration sustaining $1 / 2 I_{\max }$ was 362 cells $\mathrm{ml}^{-1}$.

\section{Short-term effects of light on growth and ingestion of Dinophysis acuminata}

During short-term experiments, phototrophic and mixotrophic growth rates of Dinophysis acuminata increased with increasing light intensity, although the latter declined slightly at the highest light intensity (i.e. $200 \mu \mathrm{E} \mathrm{m} \mathrm{m}^{-2} \mathrm{~s}^{-1}$ ) (Fig. 2a). Maximum mixotrophic and phototrophic growth rates were 0.78 and $0.34 \mathrm{~d}^{-1}$, respectively, with light intensities sustaining $1 / 2 \mu_{\max }$ being $21.5 \mu \mathrm{E} \mathrm{m}^{-2} \mathrm{~s}^{-1}$ for mixotrophic and $24.2 \mu \mathrm{E} \mathrm{m} \mathrm{m}^{-2}$ $\mathrm{s}^{-1}$ for phototrophic D. acuminata cultures. D. acuminata biovolume in prey-replete cultures was positively related to light intensity, with a maximum of $12.5 \times 10^{3}$ $\mu^{3}$ at $120 \mu \mathrm{E} \mathrm{m}^{-2} \mathrm{~s}^{-1}$ after $72 \mathrm{~h}$ (Table 2). By comparison, cell volume (mean $\pm \mathrm{SE}$ ) of $D$. acuminata in preyfree cultures showed no significant difference across light regimes, ranging from $8.1 \pm 0.6$ to $9.5 \pm 0.6 \times$ $10^{3} \mu^{3}$.

Ingestion rates of Dinophysis acuminata on Myrionecta rubra increased sharply with irradiance up to $60 \mu \mathrm{E} \mathrm{m}^{-2} \mathrm{~s}^{-1}$ (Fig. 2b). $I_{\max }$ was 2265 pg C Dinophysis ${ }^{-1}$ $\mathrm{d}^{-1}$ and light intensity sustaining $1 / 2 I_{\max }$ was $27.5 \mu \mathrm{E}$ $\mathrm{m}^{-2} \mathrm{~s}^{-1}$. Growth efficiency (GE, \%) of mixotrophic $D$. acuminata cultures was variable over different light intensities, ranging from 14 to $54 \%$ (Table 2). GE was highest at a light intensity of 30 to $120 \mu \mathrm{E} \mathrm{m} \mathrm{m}^{-2} \mathrm{~s}^{-1}$, with values on either side of that range reduced by 48 to $71 \%$.

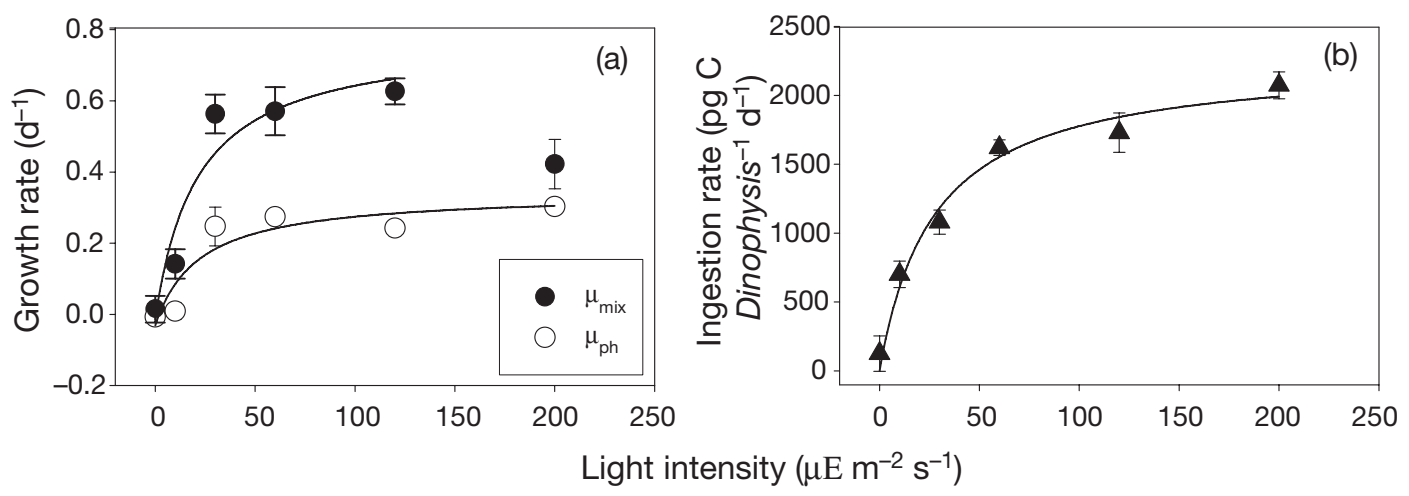

Fig. 2. Dinophysis acuminata. Short-term experiments showing (a) mixotrophic and phototrophic growth rates and (b) ingestion rate of the dinoflagellate as a function of light intensity. Data points are shown as mean \pm SE for 3 replicates. Curves were fitted by a modified Michaelis-Menten equation (Eq. 2) for growth rates and a Michaelis-Menten equation for ingestion rates. Mixotrophic growth rate $\left(\mu_{\text {mix }}, d^{-1}\right)=0.78(x-0.38) /[21.50+(x-0.38)], r^{2}=0.92$; phototrophic growth rate $\left(\mu_{\mathrm{ph}}, \mathrm{d}^{-1}\right)=0.34(x-$ $2.02) /[24.23+(x-2.02)], \mathrm{r}^{2}=0.86$; ingestion rate $\left(\right.$ pg C Dinophysis $\left.{ }^{-1} \mathrm{~d}^{-1}\right)=2265.46 x /(27.54+x), \mathrm{r}^{2}=0.98$ 
Table 2. Phototrophic growth $\left(\mu_{\mathrm{ph}}\right)$ and mixotrophic growth $\left(\mu_{\text {mix }}\right)$ rates, ingestion rate $(I)$, cell volume $(V)$ and carbon content $(C)$ of photo- and mixotrophic Dinophysis acuminata and of Myrionecta rubra, and growth efficiency (GE) of D. acuminata for cultures incubated at different light intensities. Data are shown as mean (SE in parentheses)

\begin{tabular}{|c|c|c|c|c|c|c|c|c|c|c|}
\hline \multirow{2}{*}{\multicolumn{2}{|c|}{$\begin{array}{l}\text { Light } \\
\text { intensity } \\
\left(\mu \mathrm{mol} \mathrm{m} \mathrm{m}^{-2} \mathrm{~s}^{-1}\right)\end{array}$}} & \multirow[t]{2}{*}{$\begin{array}{l}\mu_{\operatorname{mix}} \\
\left(d^{-1}\right)\end{array}$} & \multirow[t]{2}{*}{$\begin{array}{c}I \\
\left(\operatorname{pg~C~d}{ }^{-1}\right)\end{array}$} & \multicolumn{3}{|c|}{$\begin{array}{l}\text { Cell volume } \\
-\left(\times 10^{3} \mu \mathrm{m}^{3}\right)\end{array}$} & \multicolumn{3}{|c|}{$\begin{array}{l}\text { Carbon content } \\
-\left(p g \mathrm{C} \mathrm{cell}^{-1}\right)\end{array}$} & \multirow[t]{2}{*}{$\begin{array}{l}\text { GE } \\
(\%)\end{array}$} \\
\hline & & & & $V_{D-\mathrm{ph}}$ & $V_{D \text {-mix }}$ & $V_{M}$ & $C_{D-\mathrm{ph}}$ & $C_{D \text {-mix }}$ & $C_{M}$ & \\
\hline 0 & $-0.01(0.01)$ & $0.01(0.04)$ & 126 (128) & $8.2(0.7)$ & $6.4(0.9)$ & $1.6(0.2)$ & $1014(85)$ & 801 (107) & 303 (36) & - \\
\hline 10 & $0.01(0.02)$ & $0.14(0.04)$ & $701(96)$ & $9.5(0.6)$ & $8.7(0.9)$ & $1.5(0.2)$ & $1171(74)$ & $1072(104)$ & 277 (33) & $25(9)$ \\
\hline 30 & $0.25(0.05)$ & $0.56(0.05)$ & $1080(88)$ & $8.1(0.6)$ & $10.5(0.7)$ & $1.8(0.2)$ & $1006(70)$ & $1292(79)$ & 337 (35) & $54(8)$ \\
\hline 60 & $0.27(0.01)$ & $0.57(0.07)$ & $1620(57)$ & $8.5(0.2)$ & $9.4(1.0)$ & $2.1(0.2)$ & 1052 (28) & 1161 (118) & 405 (41) & $40(7)$ \\
\hline 120 & $0.24(0.00)$ & $0.63(0.04)$ & $1730(142)$ & $9.0(0.7)$ & $12.5(0.7)$ & $3.0(0.4)$ & $1114(76)$ & $1517(79)$ & 568 (69) & $50(4)$ \\
\hline 200 & $0.30(0.02)$ & $0.40(0.07)$ & $2073(97)$ & $8.7(0.6)$ & $11.9(0.8)$ & $4.3(0.6)$ & $1073(75)$ & $1452(86)$ & 809 (117) & $15(5)$ \\
\hline
\end{tabular}
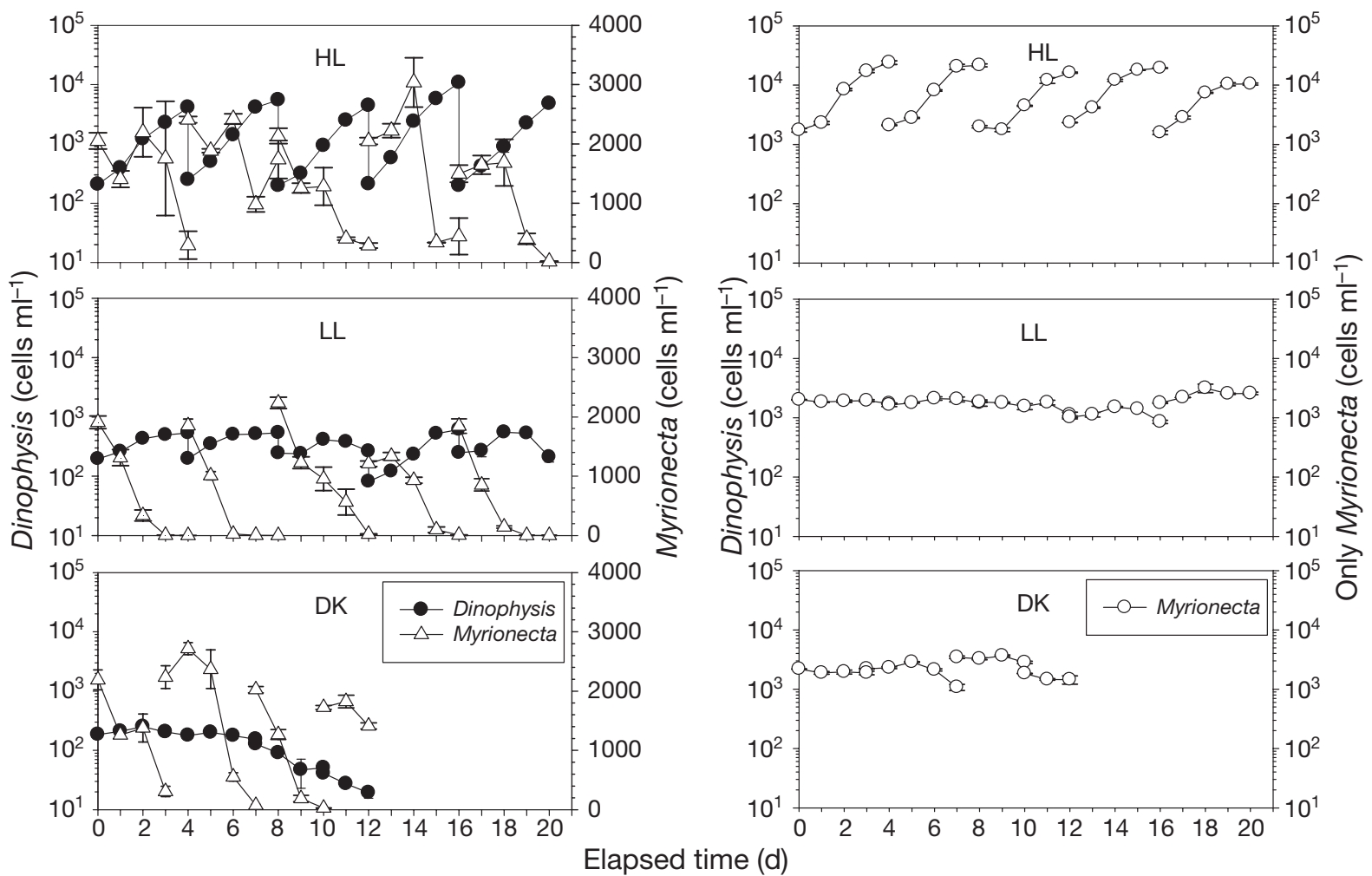

Fig. 3. Dinophysis acuminata. Long-term experiments showing growth kinetics of the dinoflagellate in semi-continuous food-

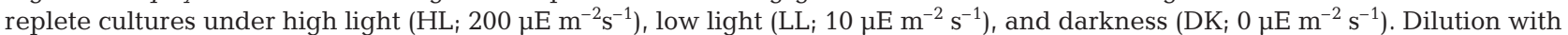
fresh f/2 medium and addition of prey Myrionecta rubra occurred periodically to return cultures to initial predator and prey concentrations. Data are shown as mean \pm SE for 3 replicates

\section{Long-term effects of light on growth kinetics of Dinophysis acuminata}

During long-term experiments, semi-continuous cultures of Dinophysis acuminata transferred and fed at 4 to $5 \mathrm{~d}$ intervals maintained exponential growth for the first 2 to $3 \mathrm{~d}$ at $200 \mu \mathrm{E} \mathrm{m} \mathrm{m}^{-2} \mathrm{~s}^{-1}$, even when prey were depleted (Fig. 3). By contrast, semi-continuous cultures in low light $\left(10 \mu \mathrm{E} \mathrm{m} \mathrm{m}^{-2} \mathrm{~s}^{-1}\right)$ entered stationary growth shortly after depletion of prey. Growth rates (mean \pm $\mathrm{SE}$ ) of $D$. acuminata over the first $48 \mathrm{~h}$ of each feeding cycle averaged $0.90 \pm 0.05$ and $0.40 \pm 0.03 \mathrm{~d}^{-1}$ in high and low light, respectively. Ingestion rates for that period were $1477 \pm 55$ and $1190 \pm 65$ pg C Dinophysis ${ }^{-1}$ $\mathrm{d}^{-1}$ in high and low light, respectively. In darkness, $D$. acuminata abundance increased slightly over the first $2 \mathrm{~d}\left(\mu=0.16 \pm 0.04 \mathrm{~d}^{-1}\right)$, remained stable over the following $5 \mathrm{~d}$, and then declined $(\mu=-0.35 \pm 0.16)$ even 
though prey were being consumed (Fig. 3). When ingestion rates for the dark incubation were estimated over the first 48 to $72 \mathrm{~h}$ of each feeding cycle, the values for the first and second cycles were $791 \pm 379$ and $664 \pm 143 \mathrm{pg}$ C Dinophysis ${ }^{-1} \mathrm{~d}^{-1}$, respectively. The ingestion rate for the third period, however, increased dramatically to $2548 \pm 556 \mathrm{pg}$ C Dinophysis ${ }^{-1} \mathrm{~d}^{-1}$. There was no apparent ingestion during the last feeding cycle.

\section{DISCUSSION}

In reviewing protistan mixotrophy, Stoecker (1998) envisioned a spectrum of strategies ranging from primarily phototrophic organisms that feed to enhance growth when nutrients or light are limiting (Model II mixotrophs), to species that are primarily phagotrophic, but use photosynthesis to supplement carbon nutrition or enhance growth when prey are limiting (Model III mixotrophs). Ideal mixotrophs (Model I) grow equally well as phototrophs or as heterotrophs, but appear to be very rare. Several studies of dinoflagellate mixotrophy have considered species fitting Model II (e.g. Akashiwo sanguinea: Bockstahler \& Coats 1993; Ceratium furca: Smalley et al. 2003; and Prorocentrum minimum: Stoecker et al. 1997), although species fitting Model III have been clearly documented (e.g. Amphidinium poecilochroum: Larsen 1988; Cryptoperidinopsis sp.: Eriksen et al. 2002; Gymnodinium gracilentum: Skovgaard 1998; and Pfiesteria piscidia: Lewitus et al. 1999b). Stoecker (1998) distinguished 2 types of Model III mixotrophs: those that are primarily phagotrophic, but that have their own plastids (Model IIIA) and those that harbor algal symbionts or sequestered prey plastids (Model IIIB). For Model IIIA organisms, carbon fixation decreases in the presence of prey. By contrast, carbon fixation by Model IIIB mixotrophs is positively related to ingestion and, thus, the availability of prey.

Dinophysis acuminata qualifies as a Model IIIB mixotroph, as ingestion of prey is required to sustain photosynthesis and growth (Park et al. 2006, this study). D. acuminata does not have algal symbionts, and sequestration of prey plastids has not been demonstrated conclusively. Recent work, however, provides strong indirect evidence supporting the notion that the cryptophye-like plastids of Dinophysis species are derived from their ciliate prey, Myrionecta rubra (Park et al. 2006, 2008).

Growth of Dinophysis acuminata increased with increasing prey concentrations, with maximum mixotrophic growth being almost 5 times higher than phototrophic growth. Mixotrophic growth rates, however, were somewhat reduced at very high prey con- centrations, even though ingestion rates remained high. Why growth decreased when ingestion remained high is uncertain, but one possibility is that high density of photosynthetic prey (Myrionecta rubra) increased $\mathrm{pH}$ of the culture medium beyond the optimal range for $D$. acuminata. That suggestion is consistent with recent reports which showed that $\mathrm{pH}$ of culture medium strongly influences growth and survival of heterotrophic, as well as phototrophic dinoflagellates (Pedersen \& Hansen 2003, Hansen et al. 2007).

Increasing light intensity had a positive effect on both phototrophic and mixotrophic growth of Dinophysis acuminata, but was more pronounced in the presence of prey, as indicated by slopes of the initial portion of fitted curves (Fig. 2). Ingestion rates also increased with light intensity, approaching saturation at irradiances giving maximum mixotrophic growth. Maximum growth in the presence of prey was roughly 3 times higher than in the absence of prey, although mixotrophic growth was reduced at the highest light intensity, showing rates similar to phototrophic growth, even though ingestion was high. There are at least 2 possible explanations for observed relationships of growth and ingestion rates with light level. Increased growth and feeding at higher irradiance may result from light-aided digestion of prey, as has been reported for other protists (Strom 2001). If true, then $D$. acuminata would be strongly heterotrophic, acquiring resources for growth through assimilation of prey biomass. Alternatively, D. acuminata may utilize essential growth factors and/or kleptoplastids from prey to support increased phototrophic growth at higher irradiances. One cannot, however, rule out a mixture of these 2 strategies. The cause for reduced mixotrophic growth at our highest irradiance, when phototrophic growth was unaffected, is more difficult to understand. If $D$. acuminata utilizes kleptoplastids, then rapid light-aided digestion at our highest irradiance may have stimulated catabolism of prey and inhibited incorporation of kleptoplastids. Conversely, rapid ingestion of prey at our highest light level may induce close packing of kleptoplastids, producing a 'self-shading' effect that limits photosynthesis and growth. In that case, reduced carbon fixation and growth should decrease the demand for resources obtained through feeding (i.e. essential nutrients and/ or kleptoplastids from prey) and thus have negative feedback on ingestion rates. Our data, however, do not support that interpretation, as ingestion rates remained high, showing even a slight increase, at our highest irradiance.

Growth of prey and predator during 2 to $3 \mathrm{~d}$ incubations as used here can result in changes in the prey: predator ratio, possibly influencing estimates of growth and ingestion rates. Based on preliminary data, 
we initiated incubations at prey to predator densities expected to generate similar mean ratios over the period used to calculate growth and ingestion. That attempt was partially successful in that the prey:predator ratio was comparable (6.7 to 9.6) at intermediate prey densities. At high prey densities (i.e. above 3000 cells $\mathrm{ml}^{-1}$ ), however, mean prey and predator densities yielded lower ratios (3.7 to 5.3). Since Dinophysis acuminata growth and ingestion rates were saturated at those prey concentrations, prey:predator ratio should not have altered our estimates. Unfortunately, the prey:predator ratio at our lowest prey density $\left(6\right.$ cells $\mathrm{ml}^{-1}$ ) was also low (2.4) and may have affected our estimates for $D$. acuminata growth and ingestion. Nonetheless, estimates for growth and ingestion at the lowest prey density fall close to curves fitted to the data and thus appear to have little influence on observed functional responses.

Dinophysis acuminata is an obligate mixotroph as it cannot grow in the absence both of prey or of light. Obligate mixotrophy has been known for many years in ciliates (Stoecker et al. 1988), but has only recently been reported for dinoflagellates (Gast et al. 2007, this study). Ingestion rates of $D$. acuminata at saturating prey densities increased with irradiance, reaching maximum values $\left(2073 \pm 97 \mathrm{pg} \mathrm{C} \mathrm{d}^{-1}\right)$ much higher than previously reported for mixotrophic dinoflagellates feeding on ciliates (710 to $888 \mathrm{pg} \mathrm{C}$ grazer $^{-1}$ $\mathrm{d}^{-1}$; Bockstahler \& Coats 1993, Smalley \& Coats 2002, Smalley et al. 2003). When normalized to grazer biomass, maximum ingestion of $D$. acuminata $\left(1.5 \mathrm{~d}^{-1}\right)$ is an order of magnitude higher than for Akashiwo sanguinea and Ceratium furca (Bockstahler \& Coats 1993, Smalley \& Coats 2002, Smalley et al. 2003). While ingestion rates increased to a maximum with increasing light level, utilization of prey resources, as indicated by our estimates for heterotrophic GE, did not. Rather, GE was highest (54\%) at intermediate light levels. It is important to note that our estimates for GE are likely overestimates, as we were only able to adjust for phototrophic growth in the absence of prey. Any enhancement of phototrophic growth due to possible photosynthesis of ingested prey plastids would be incorporated in our estimates of GE. Estimates for heterotrophic GE in other mixotrophic dinoflagellates is limited, but our values are within the range (34 to $103 \%$ ) reported for other species (Skovgaard 1998, Adolf et al. 2006, Jeong et al. 2006).

During semi-continuous incubation in the light, Dinophysis acuminata showed positive growth and ingestion for $21 \mathrm{~d}$ (23 and 12 generations under high and low light, respectively). By contrast, cultures held in the dark showed little to no growth for 6 to $7 \mathrm{~d}$ and then declined steadily. $D$. acuminata ingestion rates over the first 2 feeding cycles were moderate, in- creased sharply during the third cycle, and were undetectable in the 4 th cycle. The fact that $D$. acuminata failed to ingest prey during senescence of the cultures (Days 10 to 12) suggests either the degradation of feeding structures, or loss of signals stimulating feeding (e.g. relative cell quotas for macronutrients) during long-term absence of photosynthesis. The dramatic increase in ingestion rates observed during early decline of cultures (i.e. Days 7 to 10) was unexpected and may reflect a 'starvation' response due to the inability to fix carbon in the dark.

Blooms of Dinophysis spp. in the Baltic Sea with densities of 1.8 to $15 \times 10^{4}$ cells $1^{-1}$ typically occur near the thermocline (15 to $25 \mathrm{~m}$ for $D$. norvergica; Carpenter et al. 1995, Gisselson et al. 2002, Salomon et al. 2003), or at greater depth $(80 \mathrm{~m}$ for $D$. acuminata; Setälä et al. 2005). Since the euphotic zone in that region does not exceed 20 to 30 m (Aarup 2002), blooms of Dinophysis spp. may often be light limited. Granéli et al. (1997) indicate that maximum photosynthesis of $D$. norvegica in the Baltic Sea (108 pg C cell $\mathrm{h}^{-1}$ ) only support growth rates of $0.24 \mathrm{~d}^{-1}$. Estimates for photosynthesis at depth $(22 \mathrm{~m})$ are much lower $\left(13 \mathrm{pg} \mathrm{C}\right.$ cell $\left.\mathrm{h}^{-1}\right)$, supporting a growth rate of $0.03 \mathrm{~d}^{-1}$ (Gisselson et al. 2002). Using cell cycle analysis, Gisselson et al. (2002) estimated a growth rate of $0.4 \mathrm{~d}^{-1}$ for $D$. norvegica populations at 15 to $20 \mathrm{~m}$, while extrapolation from photosynthesis-irradiance curves indicated that photosynthesis at that depth only accounted for growth of 0.05 to $0.1 \mathrm{~d}^{-1}$. The authors thus suggested that heterotrophy likely accounted for $75 \%$ of population growth at depth, although food vacuoles were detected in only $10 \%$ of the cells. Our data for D. acuminata also indicated that phototrophic growth at low irradiance $\left(10 \mu \mathrm{mol} \mathrm{m}{ }^{-2} \mathrm{~s}^{-1}\right)$ is very slow $\left(0.01 \mathrm{~d}^{-1}\right)$ and reaches a maximum of only $0.3 \mathrm{~d}^{-1}$ at $200 \mu \mathrm{mol} \mathrm{m} \mathrm{m}^{-2} \mathrm{~s}^{-1}$. Mixotrophic growth at $10 \mu \mathrm{mol} \mathrm{m} \mathrm{m}^{-2} \mathrm{~s}^{-1}$, however, was an order of magnitude higher $\left(0.14 \mathrm{~d}^{-1}\right)$, increasing to $0.56 \mathrm{~d}^{-1}$ (about twice phototrophic growth) at $30 \mu \mathrm{mol}$ $\mathrm{m}^{-2} \mathrm{~s}^{-1}$. Whether enhanced growth in the presence of prey is the direct result of heterotrophy, as suggested by Gisselson et al. (2002), or the influence of increased photosynthesis due to acquisition of plastids or essential growth factors from prey is uncertain. Nonetheless, the generally low in situ growth rates reported for Dinophysis species (Reguera et al. 1996, Gisselson et al. 2002) suggest that these toxic dinoflagellates are typically prey limited in the natural environment. Further work is needed to fully understand the relative contribution of photosynthesis and heterotrophy to growth of $D$. acuminata.

Acknowledgements. This work was supported by the Korea Sea Grant Program to M.G.P. and the NRL (National Research Laboratory) grant from MOST \& KOSEF to W.Y. 


\section{LITERATURE CITED}

Aarup T (2002) Transparency of the North Sea and Baltic Sea: a secchi depth data mining study. Oceanologia 44: 323-337

Adolf JE, Stoecker DK, Harding LW Jr (2006) The balance of autotrophy and heterotrophy during mixotrophic growth of Karlodinium micrum (Dinophyceae). J Plankton Res 28: 737-751

Bockstahler KR, Coats DW (1993) Grazing of the mixotrophic dinoflagellate Gymnodinium sanguineum on ciliate populations of Chesapeake Bay. Mar Biol 116:477-487

Carpenter EJ, Janson S, Boje R, Pollehne F, Chang J (1995) The dinoflagellate Dinophysis norvegica: biological and ecological observations in the Baltic Sea. Eur J Phycol 30: 1-9

Eriksen NT, Hayes KC, Lewitus AJ (2002) Growth responses of the mixotrophic dinoflagellates, Cryptoperidiniopsis sp. and Pfiesteria piscicida, to light under prey-saturated conditions. Harmful Algae 1:191-203

Fields SD, Rhodes RG (1991) Ingestion and retention of Chroomonas spp. (Cryptophyceae) by Gymnodinium acidotum (Dinophyceae). J Phycol 27:525-529

Frost (1972) Effects of size and concentration of food particles on the feeding behavior of the marine planktonic copepod Calanus pacificus. Limnol Oceanogr 17:805-815

Gast RJ, Moran DM, Dennett MR, Caron DA (2007) Kleptoplasty in an Antarctic dinoflagellate: Caught in evolutionary transition? Environ Microbiol 9:39-45

Gisselson LÅ, Carlsson P, Granéli E, Pallon J (2002) Dinophysis blooms in the deep euphotic zone of the Baltic Sea: Do they grow in the dark? Harmful Algae 1:401-418

Granéli E, Anderson DM, Carlsson P, Maestrini SY (1997) Light and dark uptake by Dinophysis species in comparison to other photosynthetic and heterotrophic dinoflagellates. Aquat Microb Ecol 13:177-186

Hallegraeff GM, Lucas IAN (1988) The marine dinoflagellate genus Dinophysis (Dinophyceae): photosynthetic, neritic and non-photosynthetic, oceanic species. Phycologia 27: 25-42

> Hansen PJ, Lundholm N, Rost B (2007) Growth limitation in marine red-tide dinoflagellates: effects of $\mathrm{pH}$ versus inorganic carbon availability. Mar Ecol Prog Ser 334:63-71

Heinbokel JF (1978) Studies on the functional role of tintinnids in the Southern California Bight. 1. Grazing and growth rates in laboratory cultures. Mar Biol 47:177-189

Jacobsen DM, Anderson RA (1994) The discovery of mixotrophy in photosynthetic species of Dinophysis (Dinophyceae): light and electron microscopical observations of food vacuoles in Dinophysis acuminata, D. norvegica and two heterotrophic dinophysoid dinoflagellates. Phycologia 33:97-110

> Jakobsen HH, Hansen PJ, Larsen J (2000) Growth and grazing responses of two chloroplast-retaining dinoflagellates: effect of irradiance and prey species. Mar Ecol Prog Ser 201:121-128

> Janson S (2004) Molecular evidence that plastids in the toxinproducing dinoflagellate genus Dinophysis originate from the free-living cryptophyte Teleaulax amphioxeia. Environ Microbiol 6:1102-1106

Janson S, Granéli E (2003) Genetic analysis of the psbA gene from single cells indicates a cryptomonad origin of the plastid in Dinophysis (Dinophyceae). Phycologia 42:473-477

> Jeong HJ, Latz MI (1994) Growth and grazing rates of the heterotrophic dinoflagellate Protoperidinium spp. on red tide dinoflagellates. Mar Ecol Prog Ser 106:173-185

Jeong HJ, Ha JH, Park JY, Kim JH and others (2006) Distrib- ution of the heterotrophic dinoflagellate Pfiesteria piscicida in Korean waters and its consumption of mixotrophic dinoflagellates, raphidophytes and fish blood cells. Aquat Microb Ecol 44:263-278

Johnson MD, Stoecker DK (2005) The role of feeding in growth and the photophysiology of Myrionecta rubra. Aquat Microb Ecol 39:303-312

Koike K, Sekiguch H, Kobiyama A, Takishita K, Kawachi M, Koike K, Ogata T (2005) A novel type of kleptoplastidy in Dinophysis (Dinophyceae): presence of haptophyte-type plastid in Dinophysis mitra. Protist 156:225-237

Larsen J (1988) An ultrastructural study of Amphidinium poecilochroum (Dinophyceae), a phagotrophic dinoflagellate feeding on small species of cryptophytes. Phycologia 27: $366-377$

> Lee JS, Igarashi T, Feebvrre M (1989) Determination of diarrhetic shellfish toxins in various dinoflagellate species. J Appl Phycol 1:147-152

Lewitus AJ, Glasgow HB Jr, Burkholder JM (1999a) Kleptoplastidy in the toxic dinoflagellate Pfiesteria piscicida (Dinophyceae). J Phycol 35:303-312

Lewitus AJ, Willis BM, Hayes KC, Burkholder JM, Glasgow JB Jr, Glibert PM, Burke MK (1999b) Mixotrophy and nitrogen uptake by Pfiesteria piscicida (Dinophyceae). J Phycol 35:1430-1437

Lucas IAN, Vesk M (1990) The fine structure of two photosynthetic species of Dinophysis (Dinophysiales, Dinophyceae). J Phycol 26:345-357

Menden-Deuer S, Lessard EJ (2000) Carbon to volume relationships for dinoflagellates, diatoms, and other protist plankton. Limnol Oceanogr 45:569-579

> Minnhagen S, Janson S (2006) Genetic analyses of Dinophysis spp. support kleptoplastidy. FEMS Microbiol Ecol 57:47-54

Nishitani G, Sugioka H, Imai I (2002) Seasonal distribution of species of the toxic dinoflagellate genus Dinophysis in Maizuru Bay (Japan), with comments on their autofluorescence and attachment of picophytoplankton. Harmful Algae 1:253-264

Nishitani G, Yamaguchi M, Ishikawa A, Yanagiya S, Mitsuya T, Imai I (2005) Relationships between occurrences of toxic Dinophysis species (Dinophyceae) and small phytoplankton in Japanese coastal waters. Harmful Algae 4:755-762

Park MG, Kim S, Kim HS, Kang YG, Yih W (2006) First successful culture of the marine dinoflagellate Dinophysis acuminata. Aquat Microb Ecol 45:101-106

Park MG, Park JS, Kim M, Yih W (2008) Plastid dynamics during survival of Dinophysis caudata without its ciliate prey. $\mathrm{J}$ Phycol (in press)

Pedersen MF, Hansen PJ (2003) Effects of high pH on the growth and survival of six marine heterotrophic protists. Mar Ecol Prog Ser 260:33-41

Putt M, Stoecker DK (1989) An experimentally determined carbon:volume ratio for marine 'oligotrichous' ciliates from estuarine and coastal waters. Limnol Oceanogr 34: 1097-1103

Reguera B, Bravo L, McCall H, Reyero MI (1996) Phased cell division and other biological observations in field populations of Dinophysis spp. during cell cycle studies. In: Yahumoto T, Oshima Y, Fukuyo Y (eds) Harmful and toxic algal blooms. IOC, UNESCO, Sendai, p 257-260

Salomon P, Janson S, Granéli E (2003) Parasitism of Dinophysis norvegica by Amoebophrya sp. in the Baltic Sea. Aquat Microb Ecol 33:163-172

Sampayo MA de M (1993) Trying to cultivate Dinophysis spp. In: Smayda FJ, Shimizu Y (eds) Toxic phytoplankton blooms in the sea. Elsevier, Amsterdam, p 807-810 
Schnepf E, Elbrächter M (1988) Cryptophycean-like double membrane-bound chloroplast in the dinoflagellate, Dinophysis Ehrenb: evolutionary, phylogenetic and toxicological implications. Bot Acta 101:196-203

Setälä O, Autio R, Kuosa H, Rintala J, Ylöstalo P (2005) Survival and photosynthetic activity of different Dinophysis acuminata populations in the northern Baltic Sea. Harmful Algae 4:337-350

Skovgaard A (1998) Role of chloroplast retention in a marine dinoflagellate. Aquat Microb Ecol 15:293-301

Smalley GW, Coats DW (2002) Ecology of the red-tide dinoflagellate Ceratium furca: distribution, mixotrophy, and grazing impact on ciliate populations of Chesapeake Bay. J Eukaryot Microbiol 49:63-73

Smalley GW, Coats DW, Stoecker DK (2003) Feeding in the mixotrophic dinoflagellate Ceratium furca is influenced by intracellular nutrient concentrations. Mar Ecol Prog Ser 262:137-151

Stoecker DK (1998) Conceptual models of mixotrophy in planktonic protists and some ecological and evolutionary implications. Eur J Protistol 34:281-290

Stoecker DK, Silver MW, Michaels AE, Davis LH (1988)

Editorial responsibility: Robert Sanders,

Philadelphia, Pennsylvania, USA
Obligate mixotrophy in Laboea strobila, a ciliate which retains chloroplasts. Mar Biol 99:415-423

Stoecker DK, Li A, Coats DW, Gustafson DE, Nannen MK (1997) Mixotrophy in the dinoflagellate Prorocentrum minimum. Mar Ecol Prog Ser 152:1-12

Strom SL (2001) Light-aided digestion, grazing and growth in herbivorous protists. Aquat Microb Ecol 23:253-261

Takishita K, Koike K, Maruyama T, Ogata T (2002) Molecular evidence for plastid robbery (kleptoplastidy) in Dinophysis, a dinoflagellate causing diarrhetic shellfish poisoning. Protist 153:293-302

Vadrucci MR, Cabrini M, Basset A (2007) Biovolume determination of phytoplankton guilds in transitional water ecosystems of Mediterranean Ecoregion. Transit Waters Bull 2:83-102

Yasumoto T, Oshima Y, Sugawara W, Fukuyo Y, Oguri H, Igarashi T, Fujita N (1980) Identification of Dinophysis fortii as the causative organism of diarrhetic shellfish poisoning. Bull Jpn Soc Sci Fish 46:1405-1411

Yih W, Kim HS, Jeong HJ, Myung G, Kim YG (2004) Ingestion of cryptophyte cells by the marine photosynthetic ciliate Mesodinium rubrum. Aquat Microb Ecol 36:165-170

Submitted: September 19, 2007; Accepted: April 3, 2008 Proofs received from author(s): June 6, 2008 